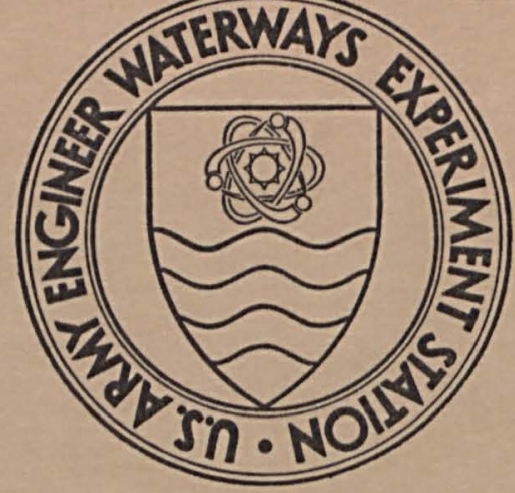

MISCELLANEOUS PAPER C-74-1

\title{
INVESTIGATION OF ACCELERATED METHODS FOR THE DETERMINATION OF AVAILABLE ALKALI IN POZZOLANS by
}

W. G. Miller
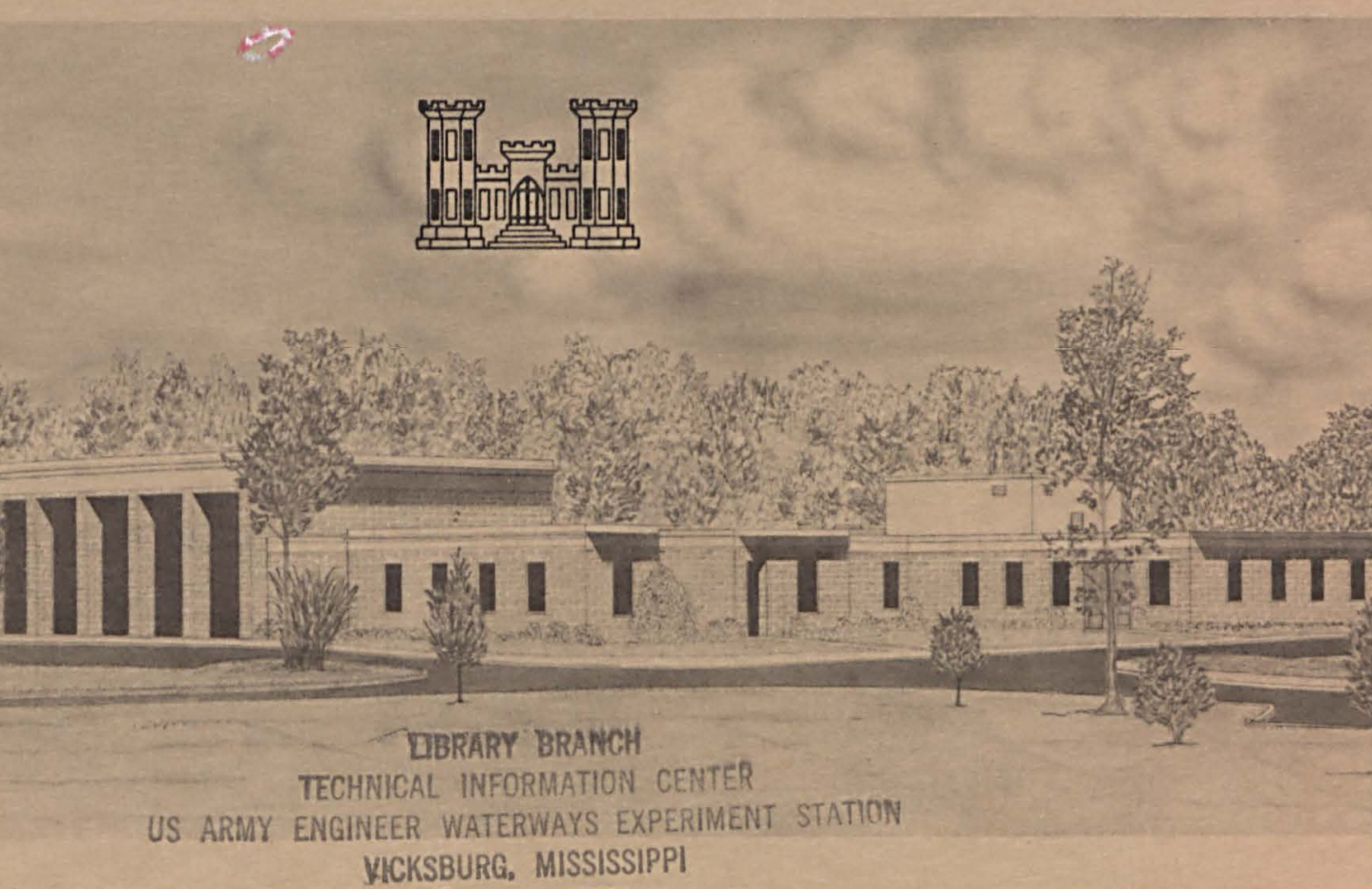

February 1974

Sponsored by Office, Chief of Engineers, U. S. Army

Conducted by U. S. Army Engineer Waterways Experiment Station

Concrete Laboratory

Vicksburg, Mississippi 


\section{Miscellaneous Paper C-74-1 \\ INVESTIGATION OF ACCELERATED METHODS FOR THE DETERMTNATION \\ OF AVAILABIE ALKALI IN POZZOIANS}

KEY

$\underline{\text { Manufacturer }}$

Oregon Portland Cement Co.

Lime, Oregon

Empire Building Mat. Co.

Portland, Oregon

Riverside Cement Co.

Crestmore, Calif.

Calif. Portland Cement Co. Mojave, Calif.

Southern Fly Ash Co. Wilsonville, Ala.

Chicago Fly Ash Co. Chicago, IIl.
Product

Volcanic Cinders

Calcined Keasey Shale

CK Sh

Calcined Diatomaceous Shale

CD Sh

Calcined Tuff

CT

Fly Ash

FA I

Fly Ash

FA II 


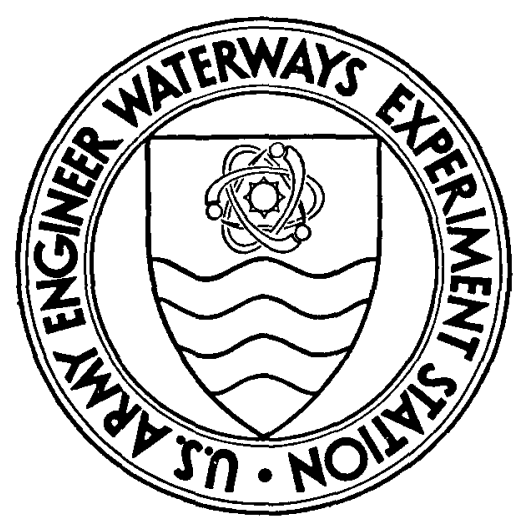

MISCELLANEOUS PAPER C-74-I

\section{INVESTIGATION OF ACCELERATED METHODS FOR THE DETERMINATION OF AVAILABLE ALKALI IN POZZOLANS

W. G. Miller

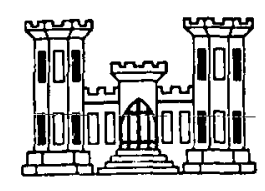

February 1974

Sponsored by Office, Chief of Engineers, U. S. Army

Conducted by U. S. Army Engineer Waterways Experiment Station

Concrete Laboratory

Vicksburg, Mississippi 
Foreword

The investigation reported herein was authorized by the office, Chief of Engineers (OCE), by the first indorsement, dated $30 \mathrm{March} 1970$, to a letter from OCE to the U.S. Army Engineer Waterways Experiment Station (WES), dated 25 February 1970, subject: "Project Plan for Investigation of Accelerated Methods for the Determination of Available Alkali in Pozzolans."

The work was conducted by the Concrete Laboratory, WES, under the direction of Mr. Bryant Mather and under the supervision of Mr. R. V. Tye, Jr. This report was prepared by Mr. W. G. Miller.

BG E. D. Peixotto, CE, and COI G. H. Hilt, CE, were Directors of WES during the preparation and publication of the report. Mr. F. R. Brown was Technical Director. 


\section{Contents}

Foreword ....................... . . . . Summary . . . . . . . . . . . . . . . . . . vil Background . . . . . . . . . . . . . . . . . 1 Purpose and Scope of Investigation . . . . . . . . . . 1 Materials and Test Methods . . . . . . . . . . . 2 Presentation and Analyses of Test Results . . . . . . . . 3 Conclusions . . . . . . . . . . . . . . . . . s Literature Cited . . . . . . . . . . . . . . 6 Tables $1-3$ 


\section{Summary}

The procedure specified in acceptance testing of pozzolans for the determination of the available alkall released by a pozzolan requires the lime-pozzolan paste to be stored for a period of 28 days prior to test. In order to investigate the possibility of reducing the storage time of the paste prior to test, six pozzolans were tested for available alkali release rate by subjecting the paste to three conditions of storage time and/or temperature. The three conditions were as follows:

$$
\begin{aligned}
& \text { a. Condition 1, standard Condition, } 28 \text { days at } 38 \mathrm{C} \text {. } \\
& \text { b. Condition 2, seven days at } 38 \mathrm{C} \text {. } \\
& \text { c. Condition 3, seven days at } 65.5 \mathrm{C} \text {. }
\end{aligned}
$$

The results of these tests are as follows:

a. The highest available alkali values for all pozzolans were obtained under Storage Condition 1.

b. All pozzolans, except calcined tuff, produced higher values for Condition 3 than for Condition 2 .

c. All pozzolans, except calcined tuff, produced available alkali values for Condition 3 that were in excess of two-thirds of the values produced for Condition 1.

Results of this study indicate that if the available alkali value of a pozzolan is 1.0 percent or less when the paste is stored at $65.5 \mathrm{C}$ for seven days, the maximum specification limit of 1.5 percent will not be exceeded when the pozzolan is evaluated by the present Standard Condition, 28 days at $38 \mathrm{C}$.

In order to reduce the storage time of the lime-pozzolan paste to seven days, storage Condition 3 with a maximum limit of 1.0 percent available alkali is recommended as an optional method for the acceptance testing of pozzolan. 


\section{INVEST IGATION OF ACCELERATED METHODS FOR THE DETERMINATION}

OF AVAILABLE ALKALI IN POZZOLANS

\section{Background}

1. The Corps of Engineers Standard Guide Specification for Concrete, $\mathrm{CE} 1401.01,1$ requires the following conditions for release for shipment and approval for use of tested pozzolans: "Release for shipment and approval for use will be based on compliance with seven-day lime-pozzolan strength requirements and other physical and chemical and untformity requirements for which test can be completed by the time the seven-day limepozzolan strength test is completed. Release for shipment and approval for use on the above basis will be contingent on continuing compliance with the other requirements of the specifications." The applicable portion of CRD-C 263, Corps of Englneers Method for Sampling and Testing Pozzolan for Use in Portland Cement Concrete, 2 for the determination of avallable alkali requires 28 days storage of the lime-pozzolan paste. Under current shipping and construction practices, most tested pozzolan is incorporated in the project construction prior to the completion of the above test.

2. This investigation was conducted as part of the responsibility assigned to the Waterways Experiment Station (WES) for the technical surveillance of cement and pozzolan procurement acceptance testing function of the Corps of Engineers as outlined in ER 1110-1-8100.3

\section{Purpose and Scope of Investigation}

3. The investigation reported herein was undertaken to determine the alkall release rate of pozzolans and was confined to the effect of 
storage time and temperature condtions on the avallable alkali released by lime-pozzolan paste prepared with pozzolans meeting the requirements of CRD-C 262, Corps of Engineers Specifications for Pozzolan for Use in Portland Cement Concrete. 2

4. This report describes the materials tested, test methods used, results obtained, and conclusions derived therefrom.

\section{Materials and Test Methods}

\section{Materials}

5. Pozzolans. From the many pozzolans available for use, six (four natural and two fly ash) were selected and identified as follows:

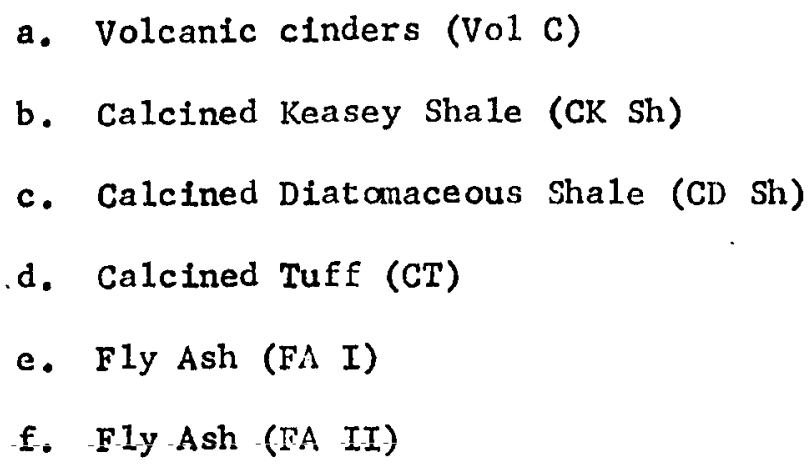

6. Each pozzolan was blended in a one-quart blender for four hours. Approximately 150 grams of each material was placed in a sealed jar and retained for chemical analysis and preparation of lime-pozzolan paste for determination of available alkali. The remaining portion was placed in a plastic bag, sealed, and retained for use in the preparation of physical test specimens.

7. Lime. The lime conformed with the requirements of ASTM Designation 66-49, "Standard Specifications for Normal Finishing Hydrated Lime."14 
8. Cement. The cement conformed with the requirements of $\mathrm{CRD}-\mathrm{C} 200$, "Federal Specification Cement, Portland."2

\section{Test Methods}

9. Tests conducted on each pozzolan were as follows:

a. Evaluation of each material for compliance with the requirements of CRD-C 262.2

b. Determination of the total acid soluble alkali in accordance with the procedure outlined in CRD-C 209, Method 1401.1 para 4.1 .2

c. Determination of water soluble alkali in accordance with the procedure outlined in ASTM C 114, "Chemical Analysis of Hydraulic Cement. "5

d. The available alkali of 1 ime-pozzolan paste was determined in accordance with the procedure outlined in CRD-C 263. Three rounds of test were conducted, a round consisting of the determination of the available alkali of each limepozzolan paste after exposure to the following storage conditions:

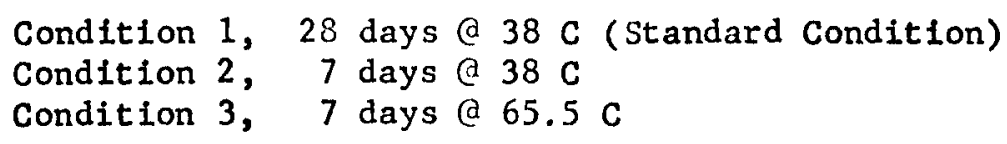

Presentation and Analyses of Test Results

10. The results of tests for compliance with CRD-C 262, acid soluble alkali,* and water soluble alkali are shown in table 1.

a. Al1 the pozzolans, except the $\mathrm{CK}$ Sh and $\mathrm{CT}$, met the requirements of CRD-C 262. The CK Sh and CT failed to comply with the minimum 75 percent of control for pozzolanic strength of cement-pozzolan mortar at 28 days.

* The method used was that used for cement. In order to determine the total alkali content of a pozzolan, the material must be rendered soluble by fusion with ammonium chloride and calcium carbonate or some other appropriate material. 
b. The test for acid soluble and water soluble alkali is not required for specification compliance and the results obtained failed to indicate any correlation with the alkali release of the pozzolans.

11. The results of tests for available alkali of 11me-pozzolan mixtures stored at three conditions of temperature and/or time are shown In table 2 .

a. All six pozzolans met the specifications requirement of 1.5 percent maximum for available alkali, calculated as $\mathrm{Na}_{2} \mathrm{O}$, after exposure to the three storage conditions.

b. A11 pozzolans, except CT, stored at a temperature of $65.5 \mathrm{C}$ for seven days, produced available alkall values in excess of two-thirds of the value obtained under standard conditions of storage.

c. The avallable alkali value for CT was lower for the sevenday $65.5 \mathrm{C}$ storage condition than the values obtained for the other two storage conditions.

12. The anomalous results for available alkali obtained for pozzolan CT prompted an examination of that material by X-ray diffraction. This study indicated the CT material to be composed of volcanic glass, a zeolite of the clinoptilolite-heulandite type, potassium feldspar, plagioclase feldspar, and quartz. The behavior of the CT material in the Iime-pozzolan paste indicates that at the $38 \mathrm{C}$ storage temperature there is an early reaction in which calcium exchanges potassium and sodium out of the zeolite. This results from the high calcium concentration of the liquid phase in the initial stage. However, it appears that at the $38 \mathrm{C}$ storage temperature the potassium and sodium concentration never becomes high enough in the liquid phase to drive the calcium out of the zeolite, therefore, a fairly high water-soluble alkali content 18 indicated at seven days. The increase in water-soluble alkali from seven days to 28 days represents either slow 
progress of the pozzolanic reaction or the additional exchange of calcium for potassium and sodium. At $65.5 \mathrm{C}$ storage temperature the diffusion rates are more rapid and this is particularly true for the monovalent cations which have larger diffusion rates. Thus if the early calcium for potassium and sodium exchange takes place, the reverse exchange takes place to a more complete extent and less water-soluble alkall is available at seven days.

\section{Conclusions}

13. Most pozzolans that produce an available alkali content of less than 1.0 percent when stored under Condition 3 would be expected to meet the specification requirement of 1.5 percent maximum when stored under Condition 1. Method 3 allows the completion of the test for available alkali in seven days and is recommended as an optional method in the acceptance testing of fly ash pozzolans. Method 3 is also recommended as an optional method for testing natural pozzolans which have been shown not to contain a zeolite. 


\section{Literature Cited}

1. Department of the Army, Office, Chief of Engineers, "Standard Guide Specifications for Concrete," CE 1401.01.

2. U. S. Army Engineer Waterways Experiment Station, CE, Handbook for Concrete and Cement, August 1949 (with Quarterly Supplements), Vicksburg, Miss.

3. Department of the Army, Office, Chief of Engineers, ER 11:10-13100 , "Laboratory Investigation and Material Testing for Military and Civil Works Construction Projects."

4. ASTM, "Standard Specification for Normal Finishing Hydrated Line," Designation C6 -49 , 1968 Book of ASTM Standards, Part 9, 1968, Philadelphia, Pa.

5. ASTM, "Chemical Analysis of Hydraulic Cement," Designation C 114, 1968 Book of ASTM Standards, Part 9, 1968, Philadelphia, Pa. 
TABIE 1

Results of Chemical Tests of Pozzolans, Percent

\begin{tabular}{|c|c|c|c|c|c|c|c|c|c|c|c|c|}
\hline Sample & $\begin{array}{l}\text { Loss on } \\
\text { Ignition }\end{array}$ & Moisture & $\mathrm{SO}_{3}$ & $\mathrm{SiO}_{2}$ & $\underline{\mathrm{R}_{2} \mathrm{O}_{3}}$ & $\begin{array}{l}\mathrm{SiO}_{2}+ \\
\mathrm{R}_{2} \mathrm{O}_{3} \\
\end{array}$ & $\underline{\mathrm{CaO}}$ & $\underline{\mathrm{MgO}}$ & $\begin{array}{l}\frac{\text { Acid Sol }}{\text { Total }} \\
\text { as } \mathrm{Na} 20 \\
\end{array}$ & $\underline{\mathrm{Na}_{2} \mathrm{O}}$ & $\underline{\mathrm{K}_{2} \mathrm{O}}$ & $\begin{array}{c}\text { Water } \\
\text { So1. A1k. } \\
\text { Total } \\
\text { as } \mathrm{Na}_{2} \mathrm{O} \\
\end{array}$ \\
\hline Vol. C & 1.69 & 0.29 & 0.38 & 54.2 & 22.6 & 76.8 & 9.9 & 3.1 & 0.52 & 0.43 & 0.14 & 0.016 \\
\hline $\mathrm{CK} S \mathrm{Sh}$ & 1.28 & 0.62 & 0.17 & 61.7 & 26.2 & 87.9 & 5.0 & 2.9 & 0.42 & 0.25 & 0.26 & 0.019 \\
\hline CT & 2.11 & 1.99 & 0.04 & 71.3 & 16.2 & 87.5 & 3.1 & 0.2 & 1.89 & 0.44 & 2.20 & 0.032 \\
\hline $\mathrm{FA} I$ & 3.56 & 0.13 & 0.85 & 51.3 & 35.6 & 86.9 & 2.9 & 1.3 & 0.17 & 0.07 & 0.15 & 0.012 \\
\hline FA II & 1.38 & 0.13 & 2.02 & 49.3 & 38.4 & 87.7 & 7.3 & 1.1 & 0.45 & 0.28 & 0.26 & 0.063 \\
\hline
\end{tabular}


TABIE 2

Results of Physical Tests of Pozzolans

\begin{tabular}{|c|c|c|c|c|c|c|c|}
\hline Samp 1e & $\begin{array}{l}\text { Specific } \\
\text { Gravity } \\
\end{array}$ & $\begin{array}{l}\text { Fineness } \\
\mathrm{Sq} \mathrm{cm} / \mathrm{cc}\end{array}$ & $\begin{array}{l}\text { Water Req. } \\
\text { Increase } \\
\text { in Flow \% }\end{array}$ & $\begin{array}{c}\text { Lime-Pozz } \\
\text { Strength, psi* }\end{array}$ & $\begin{array}{c}\text { Soundness } \\
\text { Autoclave } \\
\text { Exp..\% }\end{array}$ & $\begin{array}{l}\text { Pozz Activity } \\
\% \text { of Control } \\
\end{array}$ & $\begin{array}{c}\text { Incr. in } \\
\text { Drying } \\
\text { Shrinkage }\end{array}$ \\
\hline Vol C & 2.71 & 20,135 & 32 & 1095 & -0.01 & 86 & 0.004 \\
\hline CK Sh & 2.52 & 24,075 & 3 & 1300 & -0.02 & $74 \star \star$ & 0.006 \\
\hline $\mathrm{CD} \mathrm{Sh}$ & 2.61 & 29,825 & 17 & 1830 & -0.03 & 87 & 0.008 \\
\hline CT & 2.34 & 28,190 & 8 & 930 & 0.02 & $73 * *$ & 0.018 \\
\hline FA I & 2.23 & 8,240 & 21 & 1330 & 0.01 & 94 & \\
\hline FA II & 2.52 & 7,935 & 23 & 1155 & 0.01 & 92 & \\
\hline
\end{tabular}

* ps1 x 0.006894757 = MPa

** Failed to meet the minimum requirement of 75 percent. 
Results of Tests For Available Alkali of Pozzolans

Storage Conditions of Lime-Pozzolan Paste

Sanp le

Symbol

Vo1 C

$\mathrm{CK} \mathrm{Sh}$

$\mathrm{CD} \mathrm{Sh}$

CT

FA I

FA II
Condition ill

23 days at $33 \mathrm{C}$

Av. \% Std. Dev.

$1.43 \quad 0.065$

0.57

0.035

$0.73 \quad 0.035$

0.93

0.024

0.81

0.120

0.071

1.13

0.071

$\frac{\text { Condition } 12}{7 \text { days at } 38 \mathrm{C}}$

0.640 .053

0.29

0.047

0.48

0.024

$0.86 \quad 0.044$

0.11

0.012

0.27

0.024
0.80

$\frac{\text { Condition } \# 3}{7 \text { days at } 65.5 \mathrm{C}}$

1.01

0.040

0.43

0.029

0.67

0.018

0.48

0.019

0.76

0.035

0.012 
Unclassified

DOCUMENT CONTROL DATA - R \& D

(Security clesellication of title, body of ebatrect and indexing annotellon muat be entered when the overell pepont le ctasellled) - ORIGINA TING ACTIVITY (Comporato muthor)

U. S. Army Engineer Waterways Experiment station Vicksburg, Mississippi

2a. REPORT SECURITY CLABSIFICATION Unclassified

3. REPONT TITLE

INVESTICATION OF ACCELERATED METHODS FOR THE DETERMINATION OF AVAILABLE ALKALI IN POZZOLANS

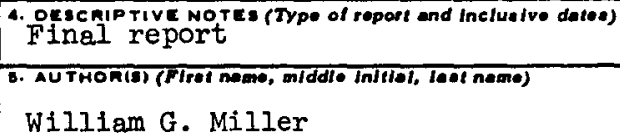

\begin{tabular}{|c|c|c|}
\hline $\begin{array}{l}\text { 6. REPORT DATE } \\
\text { February } 1974\end{array}$ & $\begin{array}{c}\text { 7a. TOTAL NO. OF PAOES } \\
13\end{array}$ & $\begin{array}{l}\text { 7b. NO. OF REFS } \\
5\end{array}$ \\
\hline B. CONTRACT OR GRANT NO. & \multicolumn{2}{|c|}{ Q0. ORIGINATOR'S REPORT NUMEERA(S) } \\
\hline b. PROJECT NO. & Miscellaneous Paper & $c-74-1$ \\
\hline c. & \multicolumn{2}{|c|}{ 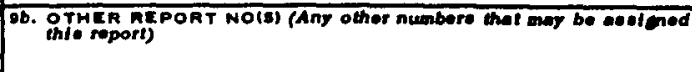 } \\
\hline d. & & \\
\hline
\end{tabular}

10. DIBTRIBUTIONSTATEMENT

Approved for public release; distribution unlimited.

\begin{tabular}{|l|l}
\hline 11. SUPALEMENTAAY NOTES & SPONGORING MILITARY ACTIVITY
\end{tabular}

13. ABstaAcT The procedure specified in acceptance testing of pozzolnns for the determination of the available alkali released by a pozzolan requires the lime-pozzolan paste to be stored for a period of 28 days prior to test. In order to investigate the possibility of reducing the storage time of the paste prior to test, six pozzolans were tested for available alkali release rate by subjecting the paste to three conditions of storage time and/or temperature. The three conditions were as follows: a. Condition 1, Standard Condition, 28 days at $38 \mathrm{c}$; b. Condition 2 , seven days-at-38-c;-c.condition 3 , seven days at $65.5 \mathrm{C}$. The results of these tests are as follows: a. The highest available alkali values for all pozzolans were obtained under storage Condition $1 . \mathrm{b}$. A.ll pozzolans, except calcined tuff, produced higher values for Condition 3 than for Condition 2. c. All pozzolans, except calcined tuff, produced available alkali values for Condition 3 that were in excess of two-thirds of the values produced for Condition 1. Results of this study indicate that if the available alkali value of a pozzolan is 1.0 percent or less when the paste is stored at $65.5 \mathrm{C}$ for seven days, the maximum specification limit of 1.5 percent will not be exceeded when the pozzolan is evaluated by the present standard Condition, 28 days at $38 \mathrm{C}$. In order to reduce the storage time of the Iime-pozzolan paste to seven days, storage Condition 3 with a maximum 1 imit of 1.0 percent available alkali is recommended as an optional method for the acceptance testing of pozzolan. 
Unclassified

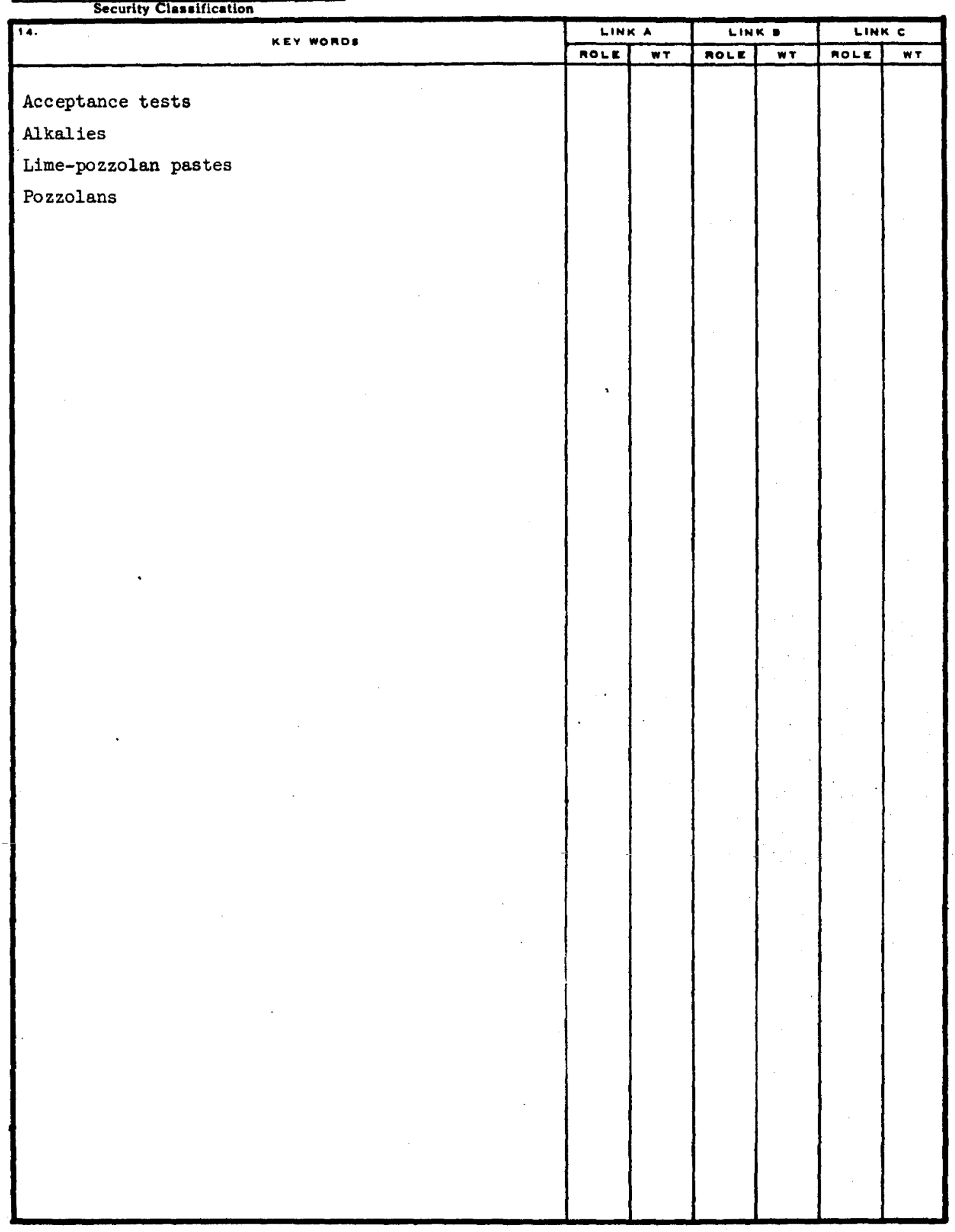

Unclass ified

Securlty Cleselfication 
In accordance w1th ER 70-2-3, paragraph $6 c(1)(b)$, dated 15 February 1973, a facsimile catalog card in Library of Congress format is reproduced below.

Miller, William G

Investigation of accelerated methods for the determination of available alkali in pozzolans, by $W$. $G$. Miller. Vicksburg, U. S. Army Engineer Waterways Experiment Station, 1974.

I v. (various pagings) 1llus. $27 \mathrm{~cm}$. (U. S. Waterways Experiment Station. Miscellaneous paper C-74-1)

Sponsored by Office, Chief of Encineers, U. S. Army. Includes bibliography.

1. Acceptance tests. 2. Alkellies. 3. Line-pozzolan pastes. 4. Pozzolans. I. U. S. Army. Corps of Engineers. (Series: U. S. Waterways Experiment Station, Vicksburg, Miss. Miscellaneous paper-C-74-1) TA7. W34m no.C-74-1 